\title{
Cleidocranial dysostosis
}

Riddhi DasGupta, ${ }^{1}$ Felix K Jebasingh, ${ }^{1}$ Hesarghatta Shyamasunder Asha, ${ }^{2}$ Nihal Thomas ${ }^{1}$

${ }^{1}$ Department of Endocrinology, Diabetes and Metabolism, Christian Medical College, Vellore, Tamil Nadu, India ${ }^{2}$ Christian Medical College, Vellore, Tamil Nadu, India

\section{Correspondence to} Dr Nihal Thomas, nihal_thomas@yahoo.com

Accepted 7 August 2015
CrossMark

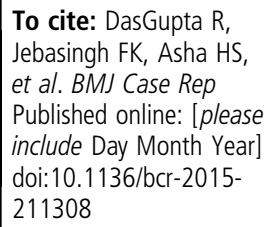

\section{DESCRIPTION}

Cleidocranial dysostosis (CCD) is a rare autosomaldominant skeletal disorder presenting with a variety of unique clinical and radiological features that can prove to be a diagnostic challenge. ${ }^{1}{ }^{2} \mathrm{~A}$ 15 -year-old boy, born of non-consanguineous parents, presented with short stature, delay in eruption of permanent teeth and facial dysmorphism. On examination, his height was $155 \mathrm{~cm}$ at the 10th centile on Agarwal's growth chart, with a midparenteral height of $165.5 \mathrm{~cm}$. He had a triangular face and hypertelorism with the lower part of his face being hypoplastic. Oral examination revealed persistent temporary milk teeth. The patient had normal secondary sexual characters. He was able to approximate his shoulders due to the presence of hypoplastic clavicles (figure 1). Laboratory tests showed a normal haemogram. His renal functions were normal with corrected serum calcium $9.2 \mathrm{mg} /$ dL (8.3-10.4), phosphate $3.2 \mathrm{mg} / \mathrm{dL} \quad(2.6-4.5)$,

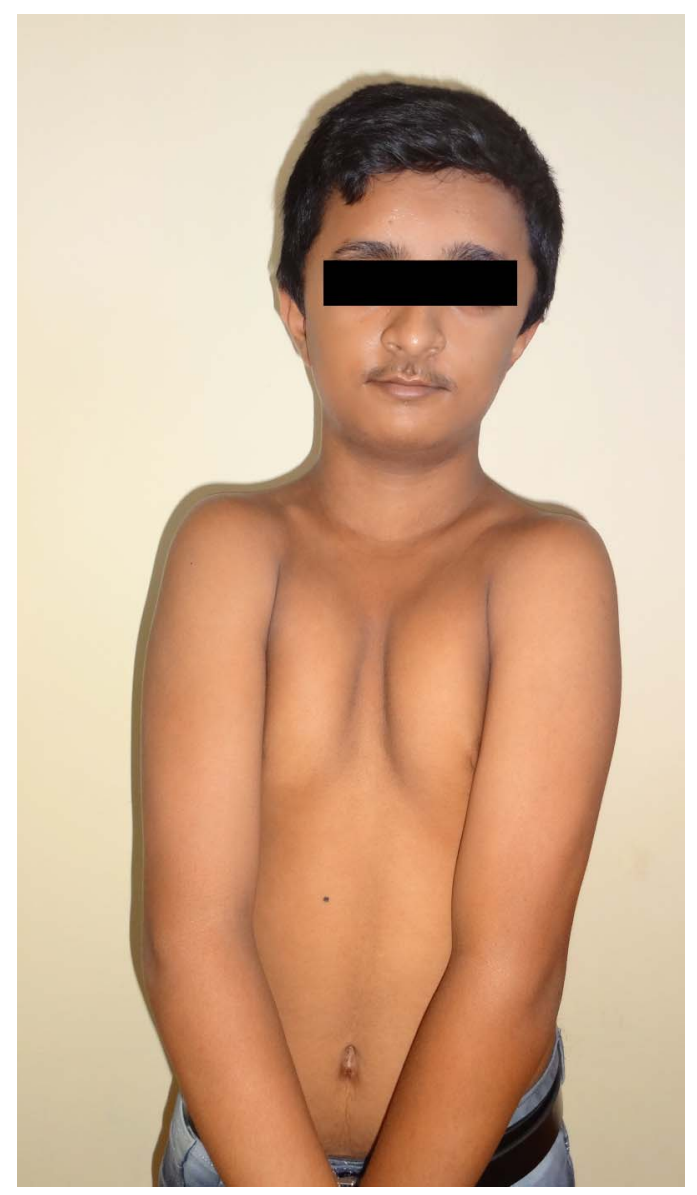

Figure 1 Patient's image showing triangular face with hypoplastic lower half and hypertelorism, suggestive of an Arnold's face and ability to approximate the shoulders, suggestive of hypoplastic clavicles.

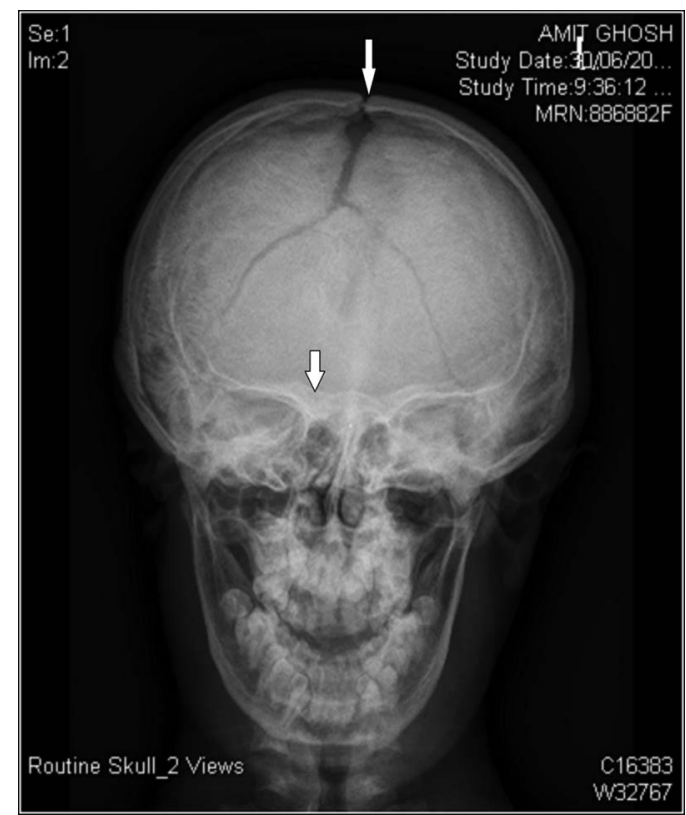

Figure 2 X-ray of the skull showing persistent opening of the anterior and posterior fontanelle and absent frontal sinus.

alkaline phosphatase $74 \mathrm{IU} / \mathrm{dL} \quad(40-125)$ and 25 -hydroxyvitamin D levels $38 \mathrm{ng} / \mathrm{dL}$. X-ray of the skull was suggestive of open anterior and posterior fontanelles with hypoplastic maxillae and absent frontal sinuses (figure 2). X-ray of the chest showed hypoplastic clavicles bilaterally (figure 3 ). In view of the clinical and radiological presentation, a diagnosis of CCD caused by mutations in the RUNX2 gene (6p21), which is involved in osteoblast differentiation and bone formation, was made. It is known that mutations with large penetrance and

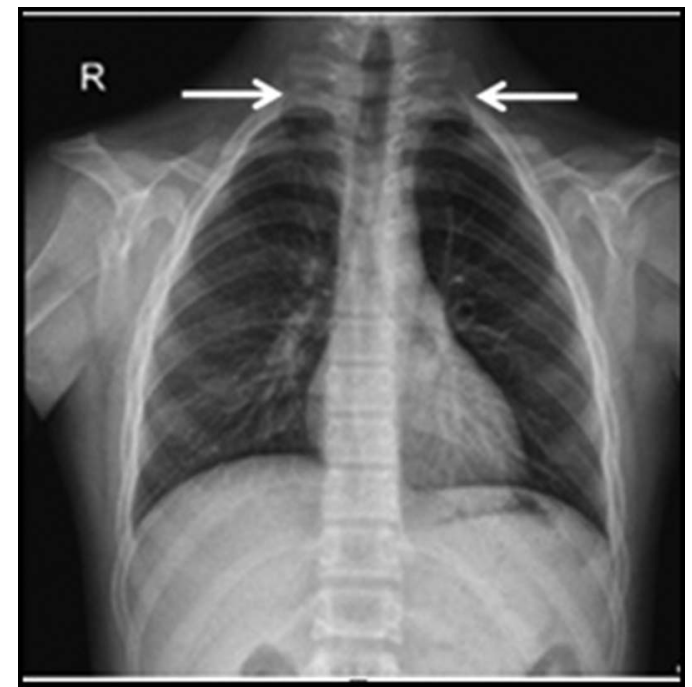

Figure 3 X-ray of the chest showing evidence of hypoplastic clavicles bilaterally. 
significant variability are involved in CCD. However, a clear correlation is not established between the phenotype and genotype. Genetic counselling should be offered to affect families as the de novo mutations are found to be high in CCD. ${ }^{3}$

\section{Learning points}

- Cleidocranial dysostosis is a benign autosomal-dominant skeletal disorder.

- Hypoplastic clavicles, open fontanelles and supernumerary teeth are the clinical clues for the diagnosis.

- The diagnosis can be confirmed by molecular genetic analysis in patients with atypical clinical and radiological features.
Contributors RD and FKJ saw the patient and wrote the article. HSA saw the patient. NT helped in writing the article.

Competing interests None declared.

Patient consent Obtained.

Provenance and peer review Not commissioned; externally peer reviewed.

\section{REFERENCES}

1 Mundlos S. Cleidocranial dysplasia: clinical and molecular genetics. J Med Genet 1999;36:177-82.

2 Bhargava P, Khan S, Sharma R, et al. Cleidocranial dysplasia with autosomal dominant inheritance pattern. Ann Med Health Sci Res 2014;4(Suppl 2): S152-4.

3 Dhiman NK, Singh AK, Sharma N, et al. Cleidocranial dysplasia. Natl J Maxillofac Surg 2014;5:206-8.

Copyright 2015 BMJ Publishing Group. All rights reserved. For permission to reuse any of this content visit http://group.bmj.com/group/rights-licensing/permissions.

BMJ Case Report Fellows may re-use this article for personal use and teaching without any further permission.

Become a Fellow of BMJ Case Reports today and you can:

- Submit as many cases as you like

- Enjoy fast sympathetic peer review and rapid publication of accepted articles

- Access all the published articles

- Re-use any of the published material for personal use and teaching without further permission

For information on Institutional Fellowships contact consortiasales@bmjgroup.com

Visit casereports.bmj.com for more articles like this and to become a Fellow 